\title{
Integration, spurious convergence, and financial fragility: a post-Keynesian interpretation of the Spanish crisis
}

\author{
Integração, convergência espúria e fragilidade financeira: \\ uma interpretação pós-Keynesiana da crise espanbola
}

ESTEBAN PÉREZ CALDENTEY* MATÍAS VERNENGO**

\begin{abstract}
RESUMO: A crise espanhola é geralmente retratada como resultado de gastos excessivos por famílias associadas a uma bolha imobiliária e/ou a um gasto excessivo de assistência social além das possibilidades econômicas do país. Apresentamos uma hipótese diferente. Argumentamos que a crise espanhola resultou, no essencial, de uma posição de déficit crescente no setor corporativo não financeiro e de uma tendência decrescente de rentabilidade sob um regime de liberalização financeira e práticas de empréstimos soltas e não regulamentadas.
\end{abstract}

PALAVRAS-CHAVE: Euro; crise macroeconômica; Espanha.

ABSTRACT: The Spanish crisis is generally portrayed as resulting from excessive spending by households associated to a housing bubble and/or an excessive welfare spending beyond the economic possibilities of the country. We put forward a different hypothesis. We argue that the Spanish crisis resulted, in the main, from a widening deficit position in the nonfinancial corporate sector and a declining trend in profitability under a regime of financial liberalization and loose and unregulated lending practices.

KEYWORDS: Euro; macroeconomic crisis; Spain.

JEL Classification: F33; F45; O52.

\footnotetext{
* Chief of the Financing for Development Unit (Economic Development Division), Economic Commission for Latin America and the Caribbean (Santiago, Chile). E-mail esteban.perez@eclac.com.

** Professor of Economics at Bucknell University (Lewisburg-PA, Estados Unidos). E-mail: mv012@ bucknell.edu. Submitted: 27/September/2016; Approved: 12/May/2017.
} 


\section{INTRODUCTION}

In the period covering 2008-2012, Spain suffered the worst economic and financial crisis in its modern history. In 2008 and 2009, GDP contracted 3.7 and $0.1 \%$ barely growing thereafter. There followed banking failures concentrated in the regionally-based savings banks and culminating in 2012 with the near collapse of the fourth largest bank, Bankia, a merger of seven regionally based savings banks. The effects of the crisis on unemployment and budget finances were rapidly felt. The rate of unemployment more than doubled between 2006 and 2009, from 8 and $18 \%$, only to increase and remain above $20 \%$ since 2010 . For its part the fiscal balance positive or near zero in the years preceding the crisis turned negative in 2008 and stabilized at roughly double digits throughout 2012.

The Spanish crisis is generally portrayed as a 'hangover' from excessive construction activity, exorbitant residential house prices, excessive spending by households and/or from the design and construction of a welfare state beyond the economic possibilities of the country. We believe that construction activity and residential house prices are a part of the explanation of the crisis, but not its main underlying cause.

We argue that the Spanish crisis resulted, in the main, from a widening deficit in the non-financial corporate sector and a declining trend in profitability under a regime of financial liberalization and loose and unregulated lending practices. The declining trend in profitability is due in part to increasing relative unit labor costs (real exchange rate appreciation) that also explain the rising imbalance in the external sector.

This led to a position of increasing financial fragility of the nonfinancial corporate sector and the external accounts with a rising and negative net international investment position (IPP). In that sense, neither the public sector profligacy, nor the patterns of consumption of the household sector are at the center of the crisis.

The paper is divided into six sections. The second section discusses Spain's economic performance from the 1961 to 2011 from an aggregate demand perspective and using the decomposition, from an accounting perspective, of the financial balances of the non-financial corporate and household sectors. The third section discusses the relationship between the increase in the imbalance of external sector and unit labor costs. Section four and five discuss Spain's sectoral financial balances and complements the analysis of the flow dimension with an examination of the stock positions of the non-corporate financial and financial sectors, and discusses the 'residential and house price bubble' hypothesis. The final thoughts are found in the last section.

\section{A BRIEF OVERVIEW OF SPAIN'S PERFORMANCE (1961-2011)}

The analysis of the evolution of GDP between 1961 and 2011 shows first that Spain witnessed a persistent growth deceleration since the 1960s until 1975 . Be- 
tween 1961 and 1975 the rate of growth of GDP averaged around $6.3 \%$, but the trend was clearly negative. Thereafter, following an unclear pattern between 1976 and 1981, the economy finally seemed to have taken off on an upward trend in 1982 reaching a peak in 1987 (one year after Spain joined the European Community in 1986). However, this proved to be transitory, with an average rate of growth of about $2.5 \%$ since the entry in the European Union until 2013, and around 2\% since the launch of the Euro.

Figure 1: Spain. Real GDP, GDP per capita growth and unemployment rate. In percentages (1961-2011)

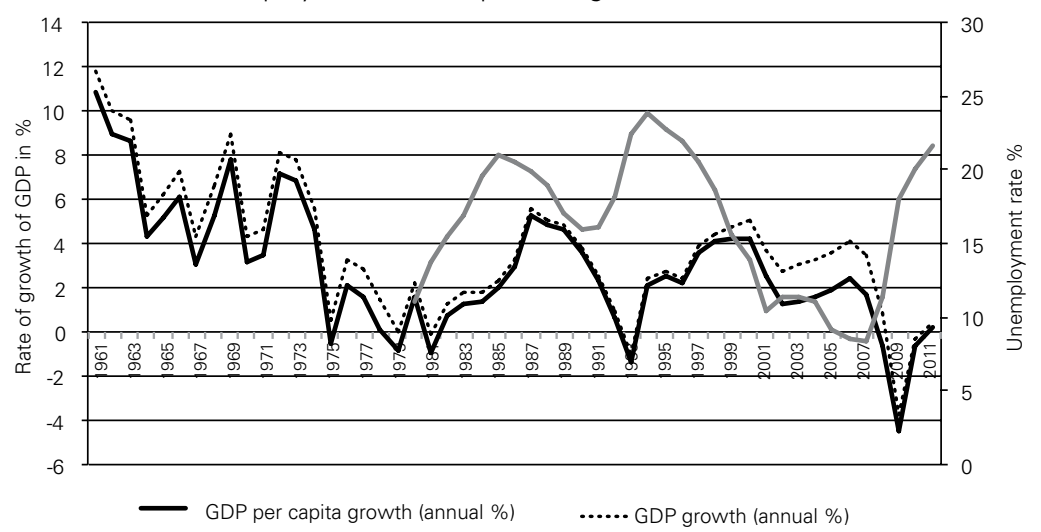

Source: World Bank Development Indicators (2015).

At the same time that GDP expanded robustly, the country confronted with success one its most difficult and persistent economic problems of its recent history, that of high unemployment. The unemployment rate that had jumped from 11 to $24 \%$ between 1980 and 1994, reaching unprecedented historical levels, was persistently abated to finally reach levels below the two-digit mark between 2001 and 2007 (10.5 and 8.3\% respectively). ${ }^{1}$ Finally during this growth period Spain registered some of lowest and more stable inflation rates in more than four decades. Between 1994 and 2007, the rate of inflation averaged 3.2\% which was below that registered for the 1960s, 1970s 1980s and 1990s (6.2, 15.4 and $9.0 \%$ respectively). ${ }^{2}$

Spain's economic performance in 1990s and 2000s can hardly be said to respond to a structural transformation or to a conscious industrial policy strategy. ${ }^{3} \mathrm{It}$

\footnotetext{
${ }^{1}$ The figures refer to total unemployment. Long-term unemployment was at $4 \%$ in 1980 and increased to $13 \%$ in 1994. In 2007 it stood at $1.7 \%$ of the total labor force.

2 The fight against is inflation was one of the main objectives of the first Socialist Party (PSOE) government (the PSOE held into power for fourteen years (1982-1996)) even to the detriment of employment. The reduction of unemployment was always secondary to the reduction in inflation.

${ }^{3}$ Prior to the entry into the European Community in 1986, the Socialist government of Felipe González
} 
can be rather explained in part by the affluence of funds received from Europe as a result of the structural fund and cohesion policies, and to private capital inflows. Between 1986 and 1996 Spain received about 150 billion Euros in funds for agriculture, for regional development and for cohesion. The majority of infrastructure development was financed with European funds, and similarly, the lion's share of tourism, foreign investment and trade originated in Europe (Carr, 2009).

But the success prior to the crisis is also explained by financial liberalization. Spain in line with the majority of Euro Zone countries lifted capital controls and deregulated interest rates towards the end of the 1980s and beginning of the 1990s. The Chinn-Ito index which reflects the degree of openness in capital account transactions shows that starting in 1992 the level of financial openness for Spain increased significantly reaching the maximum level recorded by the index by 1997 in line with those of other Euro countries (Chinn and Ito, 2006). Another important contributing factor was a policy of wage compression. As shown in Figure 2 between 1992 and 2007, the adjusted wage share trended downwards and declined from 62 to $56 \%$ of GDP.

Figure 2: Spain and European Union (15 countries) Adjusted wage share:

total economy: as percentage of GDP at current market prices

(Compensation per employee as percentage of GDP at market prices per person employed.)

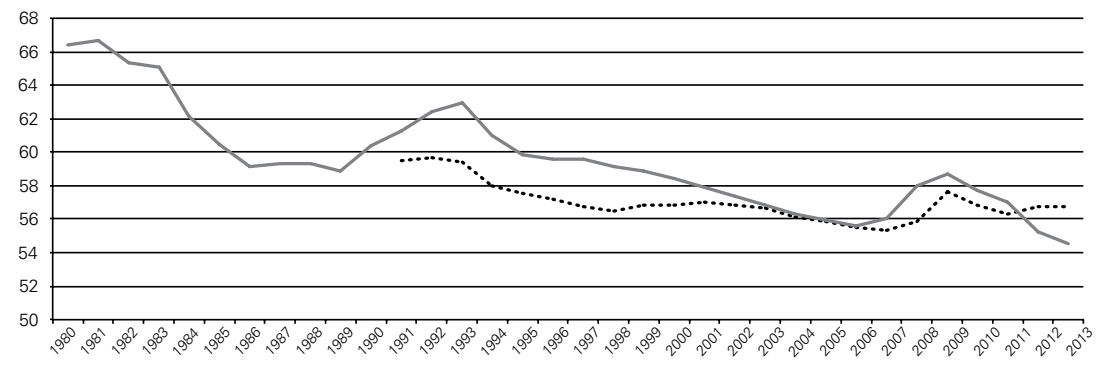

…...... European Union (15 countries) Spain

Source: AMECO (2014) http://ec.Europa.eu/economy_finance/ameco/user/serie/ResultSerie.cfm.

At the same time, the private sector including the non-financial private sectors had greater and easier access to money and liquidity and especially to short-term financing and debt, both internal and external. Finally, the term-structure of interest rates declined significantly so that European integration provided easier money and at considerably lower rates. The creation of conditions of corporate profitability, financial liberalization and wage compression were crucial in building-up a process of debt accumulation, in increasing the degree of financial fragility of the non-financial private sector and the banking system and in setting the stage for the crisis. 


\section{An analysis of the structure of aggregate demand}

A useful way to understand the drivers of growth during the period 1994-2007 is to analyze the structure of aggregate demand through the financial balances of the three major sectors of the economy, namely government $(\mathrm{FBg})$, private (FBps) and external sectors (FBes). Figure 3 below plots the financial balances of the government, external and private sectors for 1980 to 2011. It shows that between 1980 and roughly 1994 the driver of aggregate demand was the government. In this period, the fiscal accounts of the general government were systematically in a deficit position fluctuating around a $-5 \%$ of GDP 'trend' and injecting assets into the economy. In parallel, during this time the general (gross) government debt rose from 16 to 59 percent of GDP and reaching a peak in 1996 (67\% of GDP).

\section{Figure 3: Spain. Financial balances of the government, external and private sectors (1980-2011)}

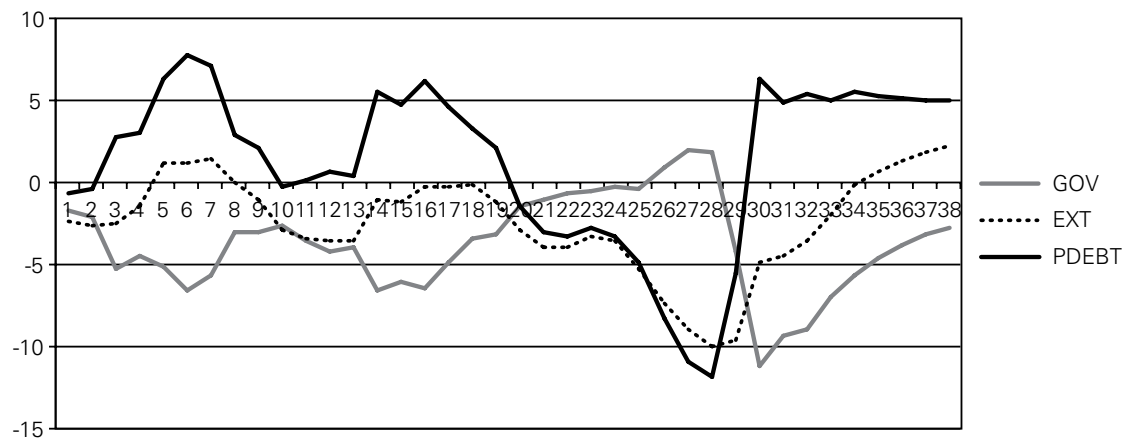

Source: IMF WEO (2015).

For its part the behavior of the private sector inversely mirrored that of the public sector. That is, as the public sector remained in deficit throughout the period, so the private sector was in permanent surplus acting as a drag on aggregate demand. More importantly, just as the public sector deficit fluctuates around a 5\% trend, the private sector surplus also fluctuates around a 5\% 'trend.' The period 1994-2008 marks a break with this pattern of aggregate demand. Starting roughly in 1994 and for more than a decade prior to the Euro crisis, the government began to adopt a contractionary fiscal stance removing its influence as a push factor of aggregate demand. The deficit declined from -6 in 1994 to $-0.3 \%$ in 1994 a decade after, and thereafter went into surplus. Public debt fell by half, from $67 \%$ of GDP in 1996 to 36 percent in 2007.

At the same time, the private sector took the leading role in sustaining the growth of aggregate demand through an increasing deficit that was, for all purposes, mirrored by the rising imbalance in the external sector. In 1994 the private sector had a surplus equivalent to $5 \%$ of GDP. By 1999 the positive financial position had turned into a deficit of $-1.5 \%$ of GDP which then progressively increased 
to a tenfold by 2007 reaching $12 \%$ of GDP. The external sector exhibited a similar behavior. In fact, as seen in Figure 3, for the period 1995-2007 it tracks the evolution the private sector.

\section{EXTERNAL IMBALANCES AND REAL EXCHANGE RATE APPRECIATION}

Spain's deterioration of its external position is explained in part by high wage costs relative to its main trade partners which resulted in an appreciation of its real exchange rate and a consequent deterioration of its external competitiveness. Table 1 plots the ratio of Spain's unit labor costs relative to those of the core European countries (Austria, Belgium, France, Germany and Netherlands) between 2000 and 2010. For this period this group of countries is the destination on average, of roughly $40 \%$ of Spain's exports. Within this group, France and Germany are the main trade partners accounting for $20 \%$ and $12 \%$ of Spain's total exports.

Table 1: Ratio of Spain's unit labor costs relative to core European countries $(2000=100)$

\begin{tabular}{|c|c|c|c|c|c|}
\hline Year/Country & Austria & Belgium & France & Germany & Netherlands \\
\hline 2000 & 100.0 & 100.0 & 100.0 & 100.0 & 100.0 \\
\hline 2001 & 102.1 & 99.4 & 100.8 & 102.7 & 98.5 \\
\hline 2002 & 104.8 & 99.9 & 100.9 & 105.4 & 97.2 \\
\hline 2003 & 107.0 & 102.3 & 102.2 & 108.0 & 98.0 \\
\hline 2004 & 110.3 & 104.8 & 103.8 & 111.6 & 100.1 \\
\hline 2005 & 112.8 & 106.9 & 105.4 & 116.5 & 103.9 \\
\hline 2006 & 115.8 & 108.2 & 106.6 & 122.5 & 106.4 \\
\hline 2007 & 119.5 & 109.8 & 109.2 & 127.9 & 108.6 \\
\hline 2008 & 122.5 & 110.4 & 111.5 & 130.7 & 110.8 \\
\hline 2009 & 117.4 & 106.6 & 109.4 & 123.9 & 106.1 \\
\hline 2010 & 115.7 & 105.5 & 107.2 & 124.3 & 106.1 \\
\hline
\end{tabular}

Note: The values presented correspond to the ratio of Spain's unit labor cost to Austria, Belgium, France, Germany and the Netherlands multiplied by 100 . All ratios have 2000 as a base year.

Source: OECD (2017).

Without exception, in all cases this ratio increases after 2002 when Spain adopted the Euro and until 2008 (one year prior to the crisis). On average, in 2001 , Spain's unit labor costs were $2 \%$ than those of the core countries. By 2008 , Spain's labor costs were $17 \%$ above the European core average. Spain registered the largest relative increase in labor costs in relation to Germany (30\% in 2008). Spain's situation was by no means unique as other peripheral European countries (Greece, Ireland, Italy and Portugal) also experienced the same phenomenon. On 
average, in 2008 , labor unitary costs were roughly $17 \%$ in the periphery relative to the core countries. ${ }^{4}$

\section{SPAIN'S SECTORAL FINANCIAL BALANCES}

A detailed presentation of the sectoral financial balances (net lending/borrowing positions) is provided in table 2 for the period 1995-2012. Besides the government and the external sector it includes financial institutions, non-financial corporations, and households. Starting in the middle of the 1990s up to the crisis households reduced their net lending position and assumed in 2004 a net borrowing position reaching $-2.7 \%$ of GDP in 2007 . Non-financial corporations became net borrowers in 1997 and increased their borrowing position throughout the 2000 s. In 2007 , non-financial corporations registered a deficit of $-10.7 \%$ of GDP, that is, three times as much as that of the household sector.

Table 2: Spain. Net borrowing/lending in percentage of GDP by sector. 1995-2012

\begin{tabular}{|c|c|c|c|c|c|}
\hline & $\begin{array}{l}\text { Non-financial } \\
\text { Corporations }\end{array}$ & $\begin{array}{c}\text { Households and } \\
\text { non-profit organizations }\end{array}$ & $\begin{array}{c}\text { Financial } \\
\text { Instituitions }\end{array}$ & $\begin{array}{c}\text { General } \\
\text { Government }\end{array}$ & ROW \\
\hline 1995 & 1.4 & 5.3 & 1.0 & -6.6 & 1.1 \\
\hline 1996 & 0.4 & 4.8 & 1.0 & -4.9 & 1.3 \\
\hline 1997 & -0.2 & 4.2 & 0.7 & -3.2 & 1.5 \\
\hline 1998 & -1.3 & 3.2 & 1.1 & -2.6 & 0.4 \\
\hline 1999 & -2.9 & 2.4 & 0.5 & -1.2 & -1.2 \\
\hline 2000 & -4.0 & 1.3 & 0.5 & -1.0 & -3.2 \\
\hline 2001 & -4.8 & 0.6 & 1.2 & -0.5 & -3.5 \\
\hline 2002 & -3.9 & 0.3 & 1.2 & -0.2 & -2.7 \\
\hline 2003 & -3.6 & 0.0 & 1.1 & -0.4 & -2.9 \\
\hline 2004 & -4.4 & -1.0 & 0.7 & -0.1 & -4.8 \\
\hline 2005 & -6.9 & -1.7 & 0.9 & 1.3 & -6.5 \\
\hline 2006 & -8.9 & -2.6 & 0.7 & 2.4 & -8.4 \\
\hline 2007 & -10.7 & -2.7 & 1.9 & 1.9 & -9.6 \\
\hline 2008 & -7.7 & 1.2 & 1.8 & -4.5 & -9.2 \\
\hline 2009 & -1.1 & 6.6 & 1.3 & -11.2 & -4.3 \\
\hline 2010 & 1.1 & 3.9 & 0.9 & -9.7 & -3.8 \\
\hline 2011 & 1.8 & 2.4 & 2.0 & -9.4 & -3.2 \\
\hline 2012 & 3.5 & 0.9 & 6.1 & -10.6 & -0.2 \\
\hline
\end{tabular}

Source: Bank of Spain Financial Accounts of the Spanish Economy and Annual Report (2000) and Methodological Notes on the Financial Accounts of the Spanish Economy (2015).

\footnotetext{
${ }^{4}$ Bresser-Pereira and Rossi (2014) focus on the role of the real exchange rate as a primary cause of the Euro Zone crisis.
} 
The persistent and growing borrowing needs of the non-financial corporate sector translated into a process of debt accumulation. Available data for 2001-2011 period shows that net debt of non-financial corporations roughly doubled from the period 2001- to 2003-2007, increasing from 646 to 1,194 as a percentage of their income, as shown in Table 3. Thereafter debt continued to increase but at a much lower pace. For the period 2008-2011, the net debt-to-income ratio reached 1,319 percent. It is worth noting that the accumulation by the non-financial corporate sector is not exclusive to Spain but that it occurs for other periphery countries also including Ireland, Italy and Portugal. Spain distinguishes itself from other periphery countries in that it registers the most rapid increase in debt prior to the crisis. Contrarily to the periphery countries, in the case of the core countries (Austria, Belgium, France, Germany and the Netherlands) the corporate sector witnessed, without exception, a decline in their stock of debt.

Table 3: Euro Zone. Net debt-to-income ratio, after taxes, of non-financial corporations. In percentages. 2001-2011

\begin{tabular}{|c|c|c|c|}
\hline & $2001-2002$ & $2003-2007$ & $2008-2011$ \\
\hline \multicolumn{3}{|c|}{ Core countries } \\
\hline Austria & 616 & 402 & 440 \\
\hline Belgium & 58 & -15 & -247 \\
\hline France & 425 & 300 & 327 \\
\hline Germany & 190 & 181 & 170 \\
\hline Netherlands & 238 & 95 & 16 \\
\hline Median & 238 & 181 & 170 \\
\hline \multicolumn{2}{|c|}{ Periphery countries } & 711 \\
\hline Italy & 353 & 430 & 327 \\
\hline Ireland & 196 & 247 & 1,319 \\
\hline Spain & 646 & 1,194 & 1,578 \\
\hline Portugal & 1,376 & 1,129 & 1,015 \\
\hline Median & 500 & 779 & 284 \\
\hline Other Euro & 229 & 210 & \\
\hline
\end{tabular}

Source: Eurostat (2015).

In order to gain a better understanding of the behavior of the financial balance of non-financial corporations we decomposed it $\left(F B_{N F C}\right)$ into its main determinants. These include non-financial corporations's gross value added $\left(G V A_{N F C}\right)$, wages $\left(W_{N F C}\right)$, taxes minus subsidies and current transfers $\left(\Omega_{N F C}\right)$, net property income $\left(N P I_{N F C}\right)$, net capital transfers $\left(N C T_{N F C}\right)$ and gross fixed capital formation $\left(I_{N F C}\right)$ and other components $\left(O C_{N F C}\right)$. Formally:

$$
F B_{N F C}=\left[\left(G V A_{N F C}\right)-\left(W_{N F C}\right)+\Omega_{N F C}\right]+\left(N P I_{N F C}\right)-\left(I_{N F C}\right)+O C_{N F C}
$$

In equation (1) the variable $W_{N F C}$ includes besides salaries social contributions 
paid by employers. $\Omega_{N F C}$ includes both taxes on production and imports, and on wealth and production. Taxes on wealth and production represent on average roughly $80 \%$ of total tax payments for the period 2000-2012. Capital taxes are included under $O C_{N F C}$. For the period under consideration capital taxes represent on average only $2 \%$ of total tax payments.

For its part net property income $\left(N P I_{N F C}\right)$ includes net interest payments and other non-interest property income. The available data shows that net interest payments accounted for roughly $50 \%$ of total net property income during 2000-2004, and thereafter took an increasingly important role in explaining its behavior. Prior to the crisis, net interest payments represented $80 \%$ of total net property income.

The term $\left[\left(G V A_{N F C}\right)-\left(W_{N F C}\right)+\Omega_{N F C}\right]+\left(N P I_{N F C}\right)$ represents the gross savings of non-financial corporations. The financial balance $\left(F B_{N F C}\right)$ can then be expressed as the difference between savings and investment. Formally,

$$
F B_{N F C}=S_{N F C^{-}} I_{N F C}+O C_{N F C}
$$

Where $S_{N F C}=\left[\left(G V A_{N F C}\right)-\left(W_{N F C}\right)+\Omega_{N F C}\right]+\left(N P I_{N F C}\right)$. Table 4 below shows the evolution of the different components of $F B_{N F C}$ on an annual basis from 2000 to 2012 as a percentage of GDP. It also provides a decomposition of its changes and that in the gross savings of non-financial institutions $\left(S_{N F C}\right)$ during three periods: 2000 -2002, 2003-2008, and 2009-2012. These three periods correspond respectively to the pre-Euro, the implementation of the Euro and the Euro crisis.

Table 4: Spain. Main components of the non-financial corporate sector financial balance 2000-2012. As percentage of GDP

\begin{tabular}{|c|c|c|c|c|c|c|c|}
\hline Year & $\begin{array}{c}\left(G V A_{N F C}\right) \\
\left(W_{N F C}\right)\end{array}$ & $\Omega_{N F C}$ & $N P I_{N F C}$ & $O C_{N F C}$ & $S_{N F C}$ & $I_{N F C}$ & $\begin{array}{c}S_{N F C} \\
I_{N F C}\end{array}$ \\
\hline 2000 & 17.7 & 3.9 & -4.0 & 0.5 & 10.3 & 14.9 & -4.6 \\
\hline 2001 & 17.7 & 3.9 & -5.1 & 0.5 & 9.1 & 14.6 & -5.5 \\
\hline 2002 & 17.6 & 4.1 & -4.4 & 0.5 & 9.7 & 14.4 & -4.7 \\
\hline 2003 & 17.5 & 4.1 & -3.9 & 0.5 & 9.9 & 14.6 & -4.6 \\
\hline 2004 & 17.7 & 4.3 & -4.3 & 0.5 & 9.5 & 15.0 & -5.6 \\
\hline 2005 & 17.1 & 4.8 & -4.5 & 0.5 & 8.3 & 15.8 & -7.5 \\
\hline 2006 & 16.8 & 5.0 & -5.2 & 0.5 & 7.1 & 16.4 & -9.3 \\
\hline 2007 & 16.4 & 5.5 & -6.0 & 0.5 & 5.5 & 16.7 & -11.2 \\
\hline 2008 & 16.9 & 3.9 & -6.5 & 0.5 & 6.9 & 15.4 & -8.5 \\
\hline 2009 & 17.8 & 3.6 & -4.9 & 0.5 & 9.8 & 11.9 & -2.0 \\
\hline 2010 & 19.4 & 3.2 & -4.4 & 0.4 & 12.3 & 11.9 & 0.4 \\
\hline 2011 & 21.2 & 3.2 & -5.1 & 0.4 & 13.3 & 12.2 & 1.2 \\
\hline 2012 & 22.7 & 3.9 & -4.4 & 0.4 & 14.9 & 11.9 & 2.9 \\
\hline & & & & & & & \\
\hline
\end{tabular}




\begin{tabular}{|c|c|c|c|c|c|c|c|}
\hline$\Delta 2000-2002$ & -0.1 & 0.2 & $\mathbf{- 0 . 4}$ & 0.0 & $\mathbf{- 0 . 7}$ & -0.5 & -0.1 \\
\hline$\Delta 2003-2008$ & -0.6 & -0.2 & $\mathbf{- 2 . 6}$ & 0.0 & $\mathbf{- 3 . 0}$ & 0.8 & -3.8 \\
\hline$\Delta 2009-2012$ & 4.9 & 0.3 & $\mathbf{0 . 5}$ & -0.1 & $\mathbf{5 . 0}$ & 0.1 & 5.0 \\
\hline
\end{tabular}

Source: Authors own on the basis of the financial accounts of the Spanish economy, Bank of Spain (2015).

The results show in the first place that the increase in the deficit position of the non-financial corporation sector $\left(F B_{N F C}\right)$, which expanded significantly after the adoption of the Euro and until the crisis, is mostly explained by a decline in the sector's gross savings and to a much lesser extent by an increase in gross fixed capital formation. During this period, the non-financial sector negative imbalance expanded by 3.8 points of GDP. The increase in investment explains 0.8 GDP points of this increase, that is, $21 \%$ of the total, and the decline in savings accounts of $3.0 \%$ age points of the total increase in the imbalance or, $79 \%$ of the total. The deterioration in the savings capacity of the non-financial corporate sector is due to net property income $\left(N P I_{N F C}\right)$. Net property income explains the bulk of the change in gross savings for this sector during the period 2003-2008. As mentioned above the behavior of net property income responds to increasing interest payments. During this period interest payments represented, on average, $40 \%$ of the sector's gross disposable income $\left(G D I_{N F C}\right)$, rising to 85 percent in some quarters in 2007 and 2008.

The decline in the savings capacity of firms and their increasing level of indebtedness and debt service payments took place against a background of decreasing profitability. This is illustrated in Table 4, which shows different indicators of profitability (gross return on capital employed, before taxes' and net return on equity after taxes) and of indebtedness (net-to-income ratio after taxes, gross debt to gross operating surplus (GOS); net debt to net operating surplus (NOS), debt-to-asset ratio; and the debt burden) for non-financial corporations. Without exception all indicators, beginning in 2002, reflect a decline in profitability. Moreover, the evidence provided in Table 4 shows that the decline in profitability preceded, according to most indicators, the increase in debt so that the latter seems to be the result of the former.

The decline in profitability accompanied by the rise in the debt of the non-financial corporate sector indicates a thrust towards greater financial fragility. The financial fragility is reflected in the fact that the number of bankrupt companies increased significantly before the onset of the crisis (IMF, 2012). In so far as the non-financial corporate sector required increasing levels of debt to fulfill its obligations and fund its working operations the sector was engaging into Ponzi finance which made its situation unsustainable over time. Firms became more exposed over time to changes in factor markets and more fundamentally to the dynamics of financial markets.

It is interesting to note that as with the case of the evolution of the debt of the non-financial corporate sector (see Table 5), the decline in profitability of that sector following the implementation of the Euro is not unique to Spain. It is also a 
characteristic of other countries of the periphery including Greece, Italy and Portugal. Contrarily the non-financial corporate sector of the 'center countries' (Austria, Belgium, France and Germany) exhibited the opposite behavior. 'Center countries' witnessed a decline in debt with a steady and convergent rise in profitability following the implementation of the Euro. The decline in profitability is due in part to the deterioration of relative labor costs which are discussed in the third section of the paper.

In this regard, it would seem that the design and policies underpinning the economic integration of Europe and the adoption of a common currency (the Euro), led to a process of divergence in the performance of the entrepreneurial sector, among the core and periphery countries. Core countries entrepreneurial sector improved its profitability and lowered its debt while the entrepreneurial sector in periphery countries witnessed a decline in profitability and an increase in debt, as can be seen in figure 4. This divergence in the performance of the real sector contrasts markedly with the convergence achieved between core and periphery countries in financial policies and nominal variables including, among others, interest rates, public debt, and inflation, which were the basis for European integration.

The convergence in financial variables did not produce convergence in the real sector. It was in a sense a spurious convergence. More importantly this process of real divergence bears an important part of the explanation of the disequilibria, including the imbalances of the external sector that were central to the onset of the Euro crisis. In this sense, real divergence proved to be extremely damaging as it undermined the very process of integration and ultimately offset the benefits of convergence.

Besides from non-financial corporations, households were the other sector that witnessed an expanding deficit with the implementation of the Euro. Although, by comparison the household sector deficit was much smaller. On average, between 2003 and 2008, the non-financial corporate imbalance was seven times as large as that of the household sector, -7.0 versus $1.1 \%$ respectively.

Figure 4: Profitability in the core and periphery countries of the Euro zone (1995-2012)

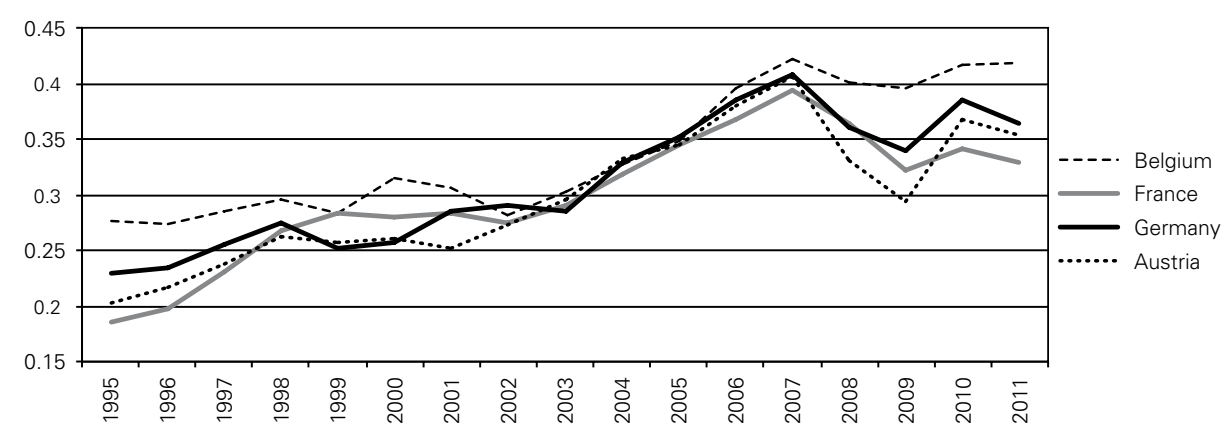




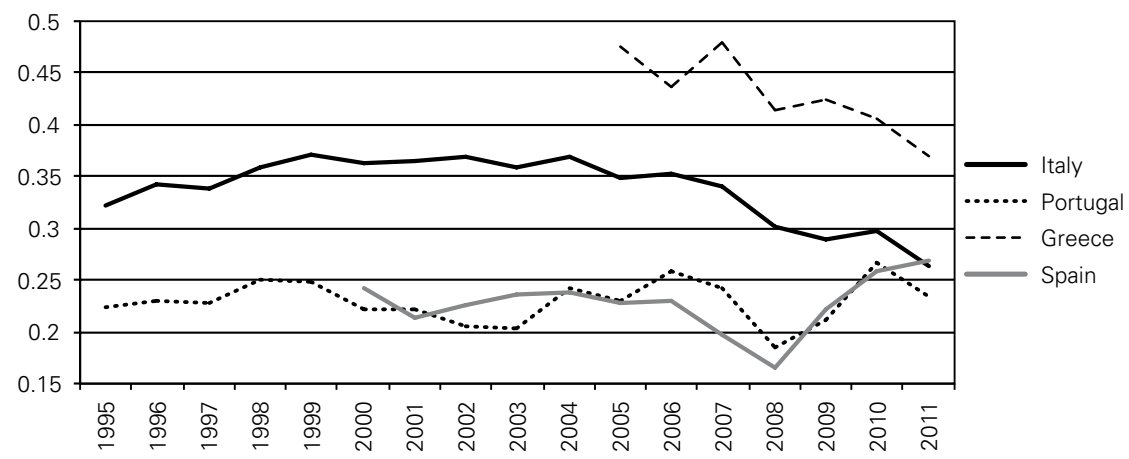

Source: Authors' own computations on the basis of Eurostat (2015).

Following the same methodology as with the non-financial corporate sector, the financial balance of the household sector can be expressed as the difference between gross savings $\left(S_{H}\right)$ and gross fixed capital formation $\left(I_{H}\right)$. Formally:

$$
F B_{H}=S_{H}-I_{H}+O C_{H}{ }^{5}
$$

Gross savings $\left(S_{H}\right)$ are in turn equal to gross disposable income $\left(G D I_{H}\right)$ minus final consumption $\left(C_{H}\right)$. That is:

$$
S_{H}=G D I_{H}-C_{H}^{6}
$$

Finally, gross disposable income $\left(G D I_{H}\right)$ is identical to the sum of gross value added $\left(G V A_{H}\right)$, wages $\left(W_{H}\right)$, net property income $\left(N P I_{H}\right)$, transfers $\left(T r_{H}\right)$, minus taxes net of subsidies $\left(T_{H}\right)$ :

$$
G D I_{H}=G V A_{H}+W_{H}+N P I_{H}+T r_{H}-\Gamma_{H}
$$

The results of the decomposition for the financial balance of the household sector show first, that the sector's deficit is a result of both a decrease in savings and an increase in gross capital formation. This stands in contrast to the evidence provided for non-financial corporations whose deficit is mainly explained by a fall in savings.

The increase in gross capital formation and the decline in savings explain most of the change in the net borrowing/lending capacity of households between in all periods. The decline in household savings $\left(S_{H}\right)$ cannot be attributed to a single variable but is explained by a conjunction of factors. These include a lower wage bill, a higher tax burden, a greater level of consumption and a minor decline in net

\footnotetext{
${ }^{5} O C_{\mathrm{H}}$ includes capital transfers and other items such as changes in inventories and net acquisitions of valuables, and net acquisitions less disposals of non-financial non-produced assets. The most important component is net capital transfers.

${ }^{6}$ Gross disposable income $\left(G D I_{\mathrm{H}}\right)$ includes social transfers in kind.
} 
property income. For the household sector, in contraposition to non-financial corporations, non-property income remained positive throughout the period. This is explained mainly by the fact that households received an increasing flow of distributed income from corporations.

The debt burden of households, measured as the sum of interest payments and principal, increased but at a slower pace than the stock of debt. The decline of the debt burden in relation to the debt stock is explained partly by the decrease in interest rates, which occurred as a consequence of the convergence criteria, contemplated by the Maastricht Treaty. Also, as important, households were able to roll over their debt over time. Households were able to roll over their debt probably because their assets had also risen significantly following the implementation of the Euro. The decomposition of the debt burden shows that interest payments remained stable throughout the first half of the 2000 s at roughly 3\% GDI reaching a $5 \%$ peak in 2007 and that the increase in the debt burden is explained by the principal. Relative to other Euro countries, the debt burden of Spanish households was by no means excessive (BBVA, 2006).

\section{THE STOCK DIMENSION AND FINANCIAL FRAGILITY}

The above sections examined the behavior of different sectors of the Spanish economy and centered more specifically on the household and non-financial corporate sectors from a flow perspective. This section completes the analysis by focusing on the balance sheet and net worth position of the same sectors. The analysis of the sectoral balance sheets shows that the corporate sector exhibited the weakest financial position of all the sectors of the Spanish economy. Available data for the period 1990 to 2011 shows a negative and deteriorating trend in the net financial worth of the non-financial corporate sector adjusted for the share and equity component. ${ }^{7}$ This simply reflects the fact that debt grew more rapidly than assets.

The deterioration of the stock position of the non-financial corporate sector began prior to the adoption of the Euro. Nonetheless, with the adoption of the Euro in 2002, the balance sheet of the non-financial corporate sector worsened further and at a faster pace. These stock results are consistent with the flow data, namely with the increasing deficit in the net financial balance of the same sector. The other sectors (with the exception of the external sector which mirrors the behavior of the non-financial corporate sector) did not exhibit a similar pattern. Data available for 2000-2011 for households, corporations and the general govern-

\footnotetext{
${ }^{7}$ Financial net worth (financial assets minus liabilities) can take on negative values because of rising values of shares and equity. To avoid this case, and capture the effect of rising debt on the net financial worth position we computed financial net worth as the difference between financial assets and liabilities, excluding shares and equity.
} 
ment shows that households exhibited a positive net worth throughout the period whose level did not vary very much between the year of the adoption of the Euro and the crisis. For its part the General Government exhibited in a consistent manner a negative net worth, albeit a declining net worth. The net financial worth of the government reached $-40 \%$ of GDP in 2001 and $-22 \%$ in 2006 and $-18 \%$ in 2007. That is the government reduced its balance sheet liability position by $50 \%$ prior to the Euro crisis.

The decomposition of the non-financial corporate sector net financial worth into its different assets and liabilities shows that in terms of assets, Spain's corporate sector became increasingly dependent on the component 'shares and other equity,' basically unquoted share excluding mutual funds. The other important component on the asset side is 'other accounts (receivable/payable)', whereas loans were not a substantive amount of total assets. On the liability side, the available evidence indicates that 'shares and other equity' represent its most important component followed by loans. On a net basis the negative financial worth of the corporate sector is explained by its increasing reliance on loans. An analysis by sources of finance of the non-corporate sector validates the above result which shows that the bulk of the finance for this sector were loans provided by the domestic financial sector. Further, the bulk of the loans were long-term loans.

From the perspective of the financial system, the evidence available since the 1990s shows that between 1993-7 and 2002-7 loans to the non-financial corporate sector rose on average from 12.1 to $27.1 \%$ of GDP. The biggest contributor to the increase in loans was the services sector. The other productive sectors including the construction (that is not services) saw minor increases in their loan portfolio when measured in terms of GDP. Households also secured an increase in loans mainly for home purchases, while loans for consumer durables rose by less than $1 \%$ of GDP. Considering the construction sector in its entirety, loans in industry and services, in households and the non-financial corporate sectors, represented 8 and $29.9 \%$ of the total on average in the period 1993-1997 and 2002-2007. In terms of the composition of the financial sector's loan portfolio, loans to construction represented 38 and $55.7 \%$ of the total for both periods (Table 5).

The analysis of the financial system's balance sheet by type of institutions shows the gain in importance of the item 'securities other than shares.' Securities other than shares represented on average $4 \%$ of the total liabilities of the financial system between 1980 and 2002 and reached above 20\% for the 2008-2013 period (Table 5). An analysis by counterpart sector shows that the most important financial instruments - currency and deposits and securities other than shares - were held by the rest of the world, $23 \%$ of deposits and $63.6 \%$ of securities other than shares). In fact the rest of the world accounted for the largest share of securities other than shares.

The significance of the sector Rest of the World as an issuer of the liabilities of the financial sector is further underscored by the fact that the position of the finan- 
cial sector vis-à-vis the rest of the world changed from net creditor to net debtor. Moreover the inflection point corresponds to the year Spain adopted the Euro.

Figure 5: Spain. Net balance sheet position of the financial sector vis-à-vis the rest of the world in billion Euro and as percentage of GDP (1989-2013).

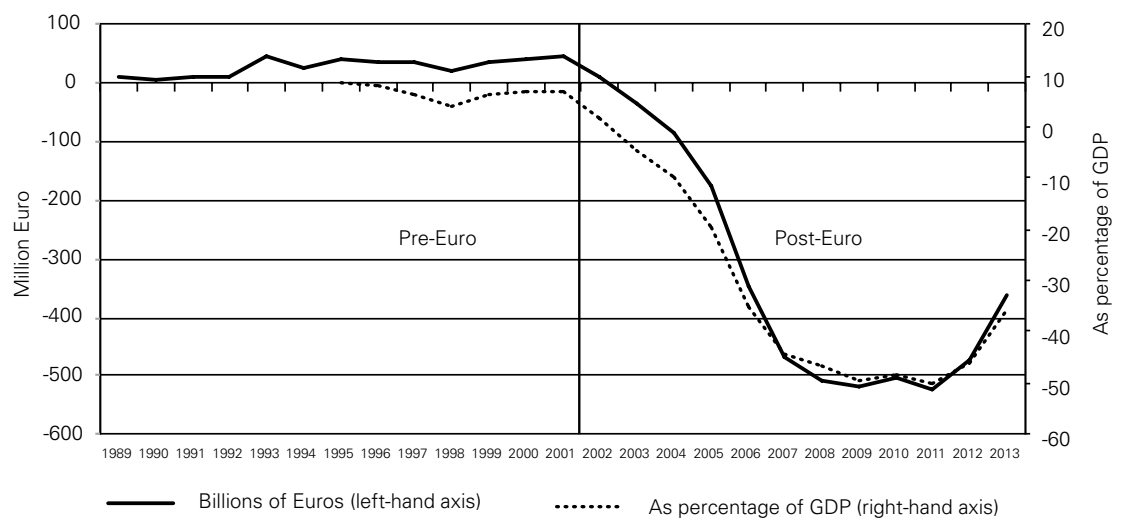

Source: Authors' own on the basis of the financial accounts of the Spanish economy. Bank of Spain (2015).

Figure 5 shows the net financial position of the financial sector with respect the external sector as a percentage of GDP between 1989 and 2013. In the period between 1989 and 2002, the position of the financial sector was without exception positive and actually increased from 8 to 45 billion Euros in 2001. Thereafter the net balance sheet position of the financial sector became increasingly negative reaching over 400 billion Euros, or the equivalent of -44 percent of GDP, in 2007 prior to the crisis.

Financial fragility, in this context, is reflected in an increased leverage that explains to a great extent the increase in the profitability of the sector following the implementation of the Euro. Available data for 1998 to 2011 shows that the rate of return over equity (ROE), a basic measure of banks profitability, experienced a steady decline between 1998 and 2003 followed by a rising trend thereafter until 2007. The rise in ROE is explained mainly by an expansion in leverage (L). From 2002 until 2007 leverage rose from 11.4 to 13.2 percent. The rate of return on assets (ROA) also increased but as the decomposition of ROA into its main components shows that this was the result of a decline in costs rather than an increase in income. ${ }^{8}$

\footnotetext{
${ }^{8}$ Profitability in the financial sector can be explained by simple banking profit identity showing that the ratio of earnings to equity equals the product of the ratio of earnings to assets and assets to equity: $R O E=\frac{\text { Earnings }}{\text { Equity }}=\left(\frac{\text { Earnings }}{\text { Assets }}\right) *\left(\frac{\text { Assets }}{\text { Equity }}\right)$, where $\frac{\text { Assets }}{\text { Equity }}=$ Leverage $(L)$ and $\frac{\text { Earnings }}{\text { Assets }}=R O A \Leftrightarrow \frac{\text { Earnings }}{\text { Equity }}=R O A * L$. In turn, $R O A=\frac{N I I+N N I I+O E-P-T}{A}$ where, $N I I=$ net interest income, NNII = net non-interest income. $\mathrm{O} E=$ operating expenses; $P^{A}=$ provisions; $T=$ taxes.
} 
The balance sheet position of the non-financial corporate and that of the financial sectors were reflected in the net International Investment Position (IPP) of the country. The IPP is the net balance between its international financial assets and liabilities. It reflects the net debtor or creditor position of the country with respect to the rest of the world, and can be interpreted as an indicator of a country's financial fragility. In the case of Spain available data for the period 1992-2013 shows that the net investment position deteriorated significantly. This stock behavior is explained by first by the significant expansion between 2002-2007 of portfolio inflows and then their reduction in 2007 prior to the contraction of GDP in 2008 and 2009 (Table 5).

Table 5: Spain. Net International Investment Position and its components in billions of Euro and as percentage of total (1992-2013)

\begin{tabular}{|c|c|c|c|c|c|}
\hline $\begin{array}{c}\text { Net } \\
\text { international } \\
\text { investment } \\
\text { position }\end{array}$ & $\begin{array}{c}\text { Net international } \\
\text { investment position } \\
\text { (excluding Bank } \\
\text { of Spain) }\end{array}$ & $\begin{array}{c}\text { Direct } \\
\text { Investment }\end{array}$ & $\begin{array}{c}\text { Portfolio } \\
\text { investment }\end{array}$ & $\begin{array}{c}\text { Other } \\
\text { investment }\end{array}$ & $\begin{array}{c}\text { Financial } \\
\text { derivatives }\end{array}$ \\
\hline 1992 & -103.7 & -46.4 & -34.1 & -23.3 & $\ldots$ \\
\hline 2002 & -363.7 & -89.2 & -105.7 & -168.9 & $\ldots$ \\
\hline 2007 & -901.7 & -2.6 & -648.5 & -231.8 & -18.8 \\
\hline 2008 & -914.0 & 1.3 & -603.7 & -305.1 & -6.4 \\
\hline 2009 & -1026.3 & -4.5 & -693.7 & -327.1 & -1.0 \\
\hline 2013 & -863.4 & -52.8 & -609.5 & -203.7 & 2.6 \\
\hline & 100.0 & 44.7 & 32.8 & 22.5 & $\ldots$ \\
\hline 1992 & 100.0 & 24.5 & 29.0 & 46.4 & $\ldots$ \\
\hline 2002 & 100.0 & 0.3 & 71.9 & 25.7 & 2.1 \\
\hline 2007 & 100.0 & -0.1 & 66.1 & 33.4 & 0.7 \\
\hline 2008 & 100.0 & 0.4 & 67.6 & 31.9 & 0.1 \\
\hline 2009 & 100.0 & 6.1 & 70.6 & 23.6 & -0.3 \\
\hline 2013 & & In bercentage of the total & & \\
\hline
\end{tabular}

Source: Authors' own on the basis of the statistical bulletin of the Bank of Spain (2015). Other investment includes loans, deposits and other investments.

The rapid expansion of portfolio net inflows during this period (Figure 6), contributed significantly to expand their stock. Further analysis focusing on portfolio investment and other investment by sector shows that by large the non-financial corporate sector and the financial sector explain the large increase in both categories. The increasing level of external indebtedness generated interest rate payment obligations that are reflected in the growing negative income balance of the balance of payments. This contributed significantly, but to a lesser extent than the imbalance in goods and services, to the generation of the external current ac- 
count deficit. This by itself can generate a cumulative process, as higher portfolio flows cause higher levels of debt and interest payments, which, in turn, expand the current account deficit which requires increasing levels of portfolio flows to fill the financing gap.

Similarly in 2007 as the country registered a sudden stop and reversal in its portfolio flows, most likely due to the contagion effects caused by the onset of the Global Financial Crisis (2007-2009), the net international investment stock position did not change substantially. In fact between 2007 and 2008, the international net investment stock position barely changed and increased slightly in 2009. Further, as portfolio flows fell credit of the financial system stopped growing and contracted moderately (see Figure 6).

Figure 6: Spain. Indices of portfolio net flows and the international and credit of the financial system to resident sectors (1992Q4-2011 Q3) (2005=100)

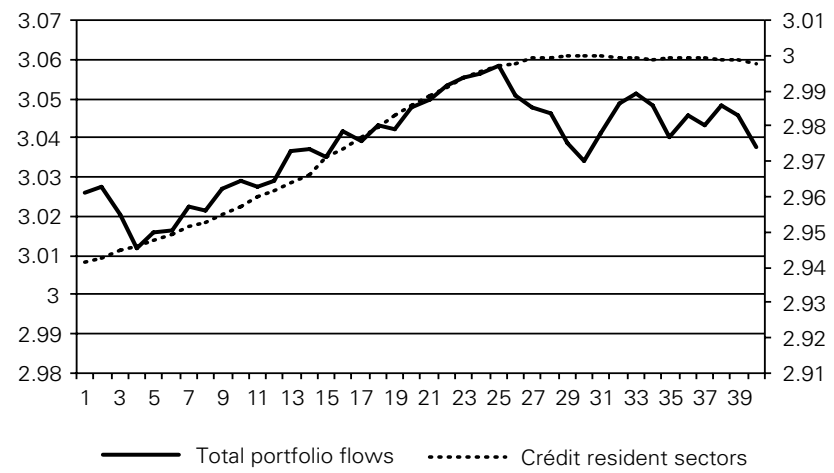

Source: Authors' own on the basis of the statistical bulletin of the Bank of Spain (2014).

This had an effect on the different sectors of the economy including on the real estate and construction sectors. Moreover, the fall in house and real estate prices further impaired the balance sheets of the financial sector and the non-financial corporate sector. In this sense, the fall in house and real estate prices was an aggravating rather than a triggering phenomenon of the Spanish crisis.

The crisis of Spain and also of the periphery countries of the Euro zone is traced in a wide part of the literature on the subject to the indebtedness of households and a corresponding bubble in the housing market, in similar fashion to the case in the United States. A cycle analysis of the data on price-to-rent, price-to-income and real price indices of housing for the period 1970-2011 shows that the upward real estate phase that Spain witnessed from the end of the 1990s to the beginning of the 2000s does not appear to be the most expansionary in Spain's recent history. Indeed, the available data also indicates that the Spanish real estate industry witnessed an expansionary phase in the later part of the 1980s that rivals the most recent one in terms of several cycle indicators.

A comparative analysis between both periods reveals that the 1980s expansio- 
nary phase exhibited greater amplitude relative to that of the 1990s-2000s, measured both in terms of percentage increase and in the compound annual growth rate. This begs the question of why if the real estate residential sector experienced important expansions in the 1980s and in the 1990s-2000s of comparable magnitude and duration, to some extent, only in the latter case was it followed by a crisis. This line of questioning is reinforced by the fact that the expansionary phase of the 1990s-2000s was not exclusive to Spain. In fact many other European countries that did not experience a crisis, such as that of the peripheral countries also experienced similar increase in the value of residential property. The rise in property values was a Euro phenomenon and more than that a European phenomenon.

\section{CONCLUSION}

The traditional explanation for external crisis is associated often to deep fiscal causes, even though the argument has serious problems, and in the European case the evidence is weak at best (Pérez Caldentey and Vernengo, 2012). The fiscal argument has never been taken seriously in the case of Spain for obvious reasons. However, the idea that in Spain the excessive spending of the private sector, associated to a bubble in housing markets and a construction boom was at the core of the crisis, has been widely accepted. Yet, the housing bubble in Spain was not out of line with similar experiences in other European countries that did not suffer with crisis.

Looking at the sectoral balance sheets of the Spanish economy reveals that fact the non-financial corporate sector rising deficit was at the center of the imbalances. This situation is explained in part by rising labor costs (real exchange rate appreciation) which were reflected in a widening external sector imbalance and, jointly with other factors, in a growing negative net financial worth balance sheet position of the non-financial corporate sector. The non-financial sector financed its deficits and debt not only via the domestic banking system, but also through external loans from other Euro zone countries. In turn, the commercial banking and financial system also required external funding becoming a net debtor vis-à-vis the rest of the world and in particular vis-à-vis the Euro zone. The majority of the external funding was portfolio investment. The balance sheet positions of the non-financial corporate sector and the financial system and their composition were reflected in a deteriorating net international investment position of the country in the aggregate, that is, the stock counterpart of the rising current account deficit.

The fragility of this process materialized when Spain experienced a sudden stop and contraction in portfolio flows mainly due to the Global Financial Crisis (2007-2009). This produced a credit crunch in the availability of finance and of credit which, given the financial position of non-financial corporate sector, put the sector against the wall. This also impaired the construction and the real estate sectors putting a downward pressure on house prices and on the value of real estate property. As a result, real estate property based assets lost their appeal affected by low 
profitability and liquidity and high carrying costs and further deteriorated the balance sheet of both the financial and non-financial corporate sectors.

The freedom of financial flows to move throughout Europe and abroad, low borrowing costs and easy access to liquidity via leveraging coupled with no exchange rate risk provided a false sense of prosperity in a low risk environment, which in the case of Spain led to the excessive leverage of the non-financial corporate sector and to a net debtor position for the country as a whole. In a sense, the fact that the Euro zone does not have mechanisms to deal with such imbalances that arise in the external accounts, and that forces austerity on debtor countries is the problem.

Note that in common currency areas, like the United States, fiscal transfers would allow for imbalances to continue without leading to contraction of output to reduce the regional balance of payments constraints. Alternatively, if the European Central Bank (ECB) had the ability to buy Euro denominated bonds of peripheral countries and keep their borrowing costs low, fiscal policy could be used by member countries, without risk of default. Hence, Lavoie (2015) is correct to note that at the heart of the problem there is a monetary sovereignty problem. On the other hand, it is also true that the manifestation of the Euro crisis is as a regular balance of payments crisis, as noted by Cesaratto (2014). It is unclear to these authors that depreciation and exit from the Euro would solve the problems of peripheral countries like Spain. On the other hand, the reform of the European institutional framework has proceeded at pace that seems too slow for the magnitude of the problems faced in the peripheral countries.

\section{REFERENCES}

AMECO (2014). "Annual Macro-economic Database of the European Commission's Directorate General for Economic and Financial Affairs (DG ECFIN).” European Commission, http://ec.Europa. eu/economy_finance/db_indicators/ameco/index_en.htm

Bank of Spain (2014) "Statistical Bulletins”. Madrid: Bank of Spain, 1998-2014.

Bank of Spain (2015) "Financial Accounts of the Spanish Economy." Madrid: Bank of Spain. Madrid: Bank of Spain. In Spanish.

BBVA (2006). Consumption Watch. Economic Research Department. https://www.bbvaresearch.com/ wp-content/uploads/2014/08/Consumption_Watch.pdf

Bresser-Pereira, L.C. \& Rossi, P. (2014) "Sovereignty, the exchange rate, collective deceit, and the Euro crisis”. Paper presented to EAEPE (European Association for Evolutionary Political Economy) Annual Conference, Cyprus, November 6-8, 2014.

Carr, R. (2009) España. 1808-2008. Revised Edition by Juan Pablo Fusi. Madrid: Ariel.

Cesaratto, S. (2014) "Balance of payments or monetary sovereignty? In search of the EMU's original sin - a reply to Lavoie," Working Paper No 2014/06, Università di Siena.

Chinn, M. D. and Ito H. (2006) "What matters for financial development? Capital controls, institutions, and interactions," Journal of Development Economics, Volume 81, Issue 1: 163-192. http://web.pdx.edu/ ito/Chinn-Ito_website.htm (updated index to 2013).

European Central Bank (2012) "Corporate indebtness in the Euro area". Monthly Bulletin. February: 87-103.

Eurostat (2015) http://ec.Europa.eu/Eurostat. 
IMF (2012) “Spain: Vulnerabilities of Private Sector Balance Sheets and Risks to the Financial Sector”. Technical Notes. IMF Country Report No. 12/140.

IMF (2015) "World Economic Outlook Database (WEO)" Washington DC. https://www.imf.org/external/pubs/ft/weo/2015/01/weodata/index.aspx

Lavoie, M. (2015) “The Eurozone: Similitudes and differences with Keynes's Plan,” Working Paper No 145, Institut für Makroökonomie und Konjunkturforschung.

Minsky, H. (1986) Stabilizing and Unstable Economy. New Haven: Yale University Press.

OECD. (2014) Banking Statistics. Paris: OECD. http://www.oecd-ilibrary.org/finance-and-investment/ data/oecd-banking-statistics_bank-data-en

OECD. (2017) Unit Labor Costs Statistics. Paris: OECD.

Pérez Caldentey, E.\& Vernengo, M. (2012) “The Euro imbalances and financial deregulation: A Post-Keynesian interpretation of the european debt crisis". Levy Institute of Bard College. Working Paper No. 702.

World Bank (2015) “World Development Indicators Online Database”. Washington DC, 2015.http:// data.worldbank.org/data-catalog/world-development-indicato 